\title{
Vignettes
}

\section{Three Pedagogical Approaches to Independent Studies}

Valerie A. Ubbes

Miami University, ubbesva@miamioh.edu

doi: 10.18833/spur/2/1/3

I have engaged dozens of students in independent studies over the last five years. Most undergraduate students have a functional literacy because they know how to read, write, and speak, but few students have adequate "performances of understanding" (Perkins and Blythe 1994) in their disciplinary major before graduation. The centrality of student self-knowledge (Baxter Magolda 2010) can be addressed in academic classrooms, but I find one-on-one independent studies with a student especially engaging when I serve as a vernacular language guide or theory interpreter to a student growing more adept at reading and talking about peer-reviewed journal articles in my office. Sometimes, when the semester-long discussions culminate with an undergraduate research poster at the university student center, the student gains further agency in using the language of the discipline and showing what they know to a host of other people with different backgrounds and perspectives. Such human interactions cannot really be taught, only experienced. These social constructions of meaning making are called learning episodes.

My first goal when establishing an independent study with a student is to find common ground for negotiating a mutually rewarding topic. This means I listen well to who my student is and wants to be and what he or she is thinking about at the orientation meeting, so I can offer some piece of my scholarship related to his or her interest. Question posing and question framing become key processes of my inquiry-based pedagogy (Ubbes 2008). I probe gently with "whys" during the first meeting but prefer to ask more "what," "when," and "how" questions to empower the student as the storyteller who can coauthor the independent study.

My second goal is to give each student a learning space for talking about what seems important in the reading that day. I focus on setting up a teaching-learning environment where the student grows comfortable personalizing and theorizing what he or she knows and does not know, including what the learner might like to find out for the next week. I explicitly talk about the reading, writing, and talking processes of learning a discipline with its specialized vocabulary and use questions to help the student think deeply. Can he or she talk easily from a reading or is a writing prompt needed to help think about the reading? Can the student write some questions for an author and then discuss what he or she wants to know about the author's theory, model, or research study? In short, a constructivist-developmental pedagogy is used to support the cognitive, social, and affective maturation of the student as thinker. Co-construction of self-knowledge and disciplinary knowledge often involves the use of technology as a cultural tool for negotiating a performance of understanding with words, images, numbers, rhythms, and body language (Ubbes 2008).

My third goal is to model a relational pedagogy (Ubbes 2008) as I encourage the learner to tell stories about the reasons for selecting a particular major, the potential venues for work experiences, and the individuals who serve as significant mentors to him or her. Because the weekly interaction is all about mutual meaning-making, I reciprocate with a story or two about my research and weave it into the discussions. A student may need support in accomplishing a career goal by applying for a scholarship, finalizing a resume, or negotiating a summer job interview. A relational pedagogy can help students develop a vocational path through self-authorship as they move from an absolute knower into a transitional knower or from a transitional knower into an independent knower (Baxter Magolda 2010). Building a relationship with me as mentor, scholar, and learner means that the independent knower now joins the profession as a collaborator and constructor of knowledge. Knowing when, how, and with whom to use that knowledge creates a contextual knower-an academic scholar.

\section{References}

Baxter Magolda, Marcia. 2010. "The Interweaving of Epistemological, Intrapersonal, and Interpersonal Development in the Evolution of Self-Authorship." In Development and Assessment of Self-Authorship: Exploring the Concept across Cultures, ed. Marcia Baxter Magolda, Elizabeth G. Creamer, and Peggy S. Meszaros, 25-43. Sterling, VA: Stylus.

Perkins, David, and Tina Blythe. 1994. "Putting Understanding Up Front.” Educational Leadership 51(5): 4-7.

Ubbes, Valerie A. 2008. Educating for Health: An InquiryBased Approach to PreK-8 Pedagogy. Champaign, IL: Human Kinetics. 